\title{
Field Efficacy of Botanicals and Inorganic Salts against Mosaic Disease on Ridge Gourd in Western Rajasthan
}

\author{
S. K. Maheshwari*, B. R. Choudhary, P. L. Saroj and B. D. Sharma \\ ICAR-Central Institute for Arid Horticulture, Bikaner- 334006 (Rajasthan), India \\ *Corresponding author
}

A B S T R A C T

Keywords

Botanicals, inorganic salts, Efficacy, Mosaic disease, Ridge gourd

Article Info

\section{Accepted:}

11 June 2020 Available Online: 10 July 2020
Ridge gourd [Luffa acutangula (Roxb.) L.] is an important vegetable crop and it is grown in different parts of India. The field trials were conducted during rainy season of 2018 and 2019 to test efficacy of botanicals and inorganic salts against management of mosaic disease in ridge gourd. In this study, naturally infected leaf samples exhibiting characteristic mosaic disease symptoms were collected during experiments. Among 11 treatments, imidacloprid (@ $0.05 \%$ ) was found the most efficient treatment against mosaic disease with minimum per cent disease index $(15.90 \%)$ and per cent disease reduction (61.69\%). Next best treatment was neem leaf extract (@ 10\%) with per cent disease index of $19.34 \%$ and per cent disease reduction of $53.41 \%$, followed by tumba fruit extract @ 10\% (21.18\% PDI and $48.97 \%$ disease reduction). Least effective treatment was borex (500 ppm) with PDI of $36.89 \%$, followed by salicylic acid (500 ppm) with PDI of $35.36 \%$ against mosaic disease on ridge gourd in pooled data.

\section{Introduction}

Ridge gourd [Luffa acutangula (Roxb.) L.] commonly known as 'kalitori', angled gourd, angled loofah or ribbed gourd, is an important cucurbitaceous crop, which is consumed as vegetable. Vegetables are the best source for overcoming nutrient deficiencies and provide per unit area high income to the small and marginal farmers. Ridge gourd is one of the most important cucurbitaceous vegetable crops from nutritional as well as economic point of view. The fruits are very nutritious and good source of calcium, phosphorus, ascorbic acid, iron and fibre content (Aykroyd, 1963). It is grown in different parts of India, central and eastern Asia to south eastern for tender fruits. It is well known for preparations of curries in India, which is easily digestible and prevent constipation with good nutritive value and high yield potential (Seshadri, 1986). It is beneficial for jaundice patients and cure for tetanus (Pal and Jain, 1998). A number of angiospermic plants have 
been reported to possess antimicrobial activity, which is a potential alternate for chemical control (Yamaguchi, 1996). This crop has the ability to tolerate moderate to high temperature which ensures its adaptability for wide spread cultivation throughout the tropics. However, the climatic conditions of western Rajasthan are altogether different from other parts of India which is characterized by very high potential evapotranspiration rate, intense solar radiations $\left(320-619 / \mathrm{cm}^{2} /\right.$ day), high wind velocity (20 $\mathrm{km} / \mathrm{hr}$ ), high infiltration $(9 \mathrm{~cm} / \mathrm{hr})$, extremes of temperature $\left(0\right.$ to $\left.48^{\circ} \mathrm{C}\right)$, low relative humidity, low soil fertility, high soil $\mathrm{pH}$, saline ground water, etc. (More, 2010). Under such harsh climatic conditions, cultivation of existing ridge gourd varieties results in very low and poor quality yield which fetches less return per unit area.

Plant extracts that possess secondary compounds as well as water soluble alkaloids and other bioactive compounds have been investigated with regard to their potential for controlling phytopathogens (Stangarlin et al., 2011; Alpa et al., 2010). The crop is attacked by a number of diseases such as Alternaria leaf blight, downy mildew, mosaic disease and amongst which, mosaic disease is found to cause serious losses throughout Rajasthan and other states in India. During 1999 crop season, an epidemic of mosaic disease was prevalent on muskmelon, cucumber and squash in Punjab and in adjoining states causing huge fruit losses to the crops. Mosaic disease symptoms in ridge gourd can vary greatly depending on the crop infected and the age of the plant when infection occurs. Infected plants show leaf mosaic, leaf distortion, stunting, mottling and yellowing. So far, information available on this aspect in ridge gourd under western Rajasthan is scanty. Keeping in view, the present study was undertaken to test the efficacy of botanicals and inorganic salts against mosaic disease of ridge gourd under field conditions.

\section{Materials and Methods}

Field trials were conducted at Pathology Block of ICAR-Central Institute for Arid Horticulture, Bikaner (Rajasthan) located at $28^{0} \mathrm{~N}$ latitude, $73^{0} 18^{1} \mathrm{E}$ longitude at an altitude of $234.84 \mathrm{~m}$ above sea level during rainy season of 2018 and 2019 in randomized block design with three replications. Ridge gourd variety 'Jaipur Long' was sown after seed treatment by soaking in the extract of respective treatment for 05 minutes to 30 minutes. In the last week of July during both the years (2018 and 2019) and tested against mosaic disease. The spacing maintained between rows was $2.0 \mathrm{~m}$ and between plants $0.50 \mathrm{~m}$. Eleven treatments such as neem leaf extract@5\%,neem leaf extract@10\%, neem seed kernel extract @ 5\%,tumba fruit extract@5\%,tumba fruit extract@10\%, aak leaf extract@5\%), aak leaf extract@10\%, 02 inorganic salts like salicylic acid@ 500 ppm and borex @ 500 ppm, one insecticide namely imidacloprid (@ 0.05\%) and control (treatment of untreated check without spray) were taken for this study during both the years (2018 \& 2019).

Neem (Azadirachta indica), tumba (Citrullus colocynthis) and aak (Calotropis gigantean) plants were used as extracts. The plant parts used were leaf (neem and aak), seed kernel (neem) and fruits (tumba). Empirically, plant extracts have been used in non-conventional agriculture production systems for the control of plant diseases. Such extracts are often produced in a homemade fashion from materials available on the property that are sprayed on the crops (Silva et al., 2005). In order to obtain the aqueous extracts, the plant material was collected locally, thoroughly washed using tap water to remove the dusts and crushed in sterile distilled water @ of $1 \mathrm{~g}$ tissue $/ \mathrm{ml}$ of water $(1: 1 \mathrm{w} / \mathrm{v})$ using sterilized pestle and mortar. The aqueous extract was partially purified by passing through a double layer of muslin cloth. The filtrate was used as 
plant extract of $100 \%$ concentration. Neem seed kernels and tumba fruits were finely ground separately and soaked in water over night. The mixture was filtered. Further dilutions were made of the extracts with sterile distilled water to get desired concentrations (Jain and Agrawal, 2011). The activity of aqueous plant extracts at $5 \%$ and $10 \%$ concentrations of each botanicals were sprayed on the crops against mosaic disease.

Mosaic disease was observed in the field during both the years. The recommended packages of practices for this crop were adopted. Three sprays of each treatment were done in the crop. First spray was applied after 20-30 days of sowing. The second and third sprays of same concentration were done at 07 days interval. Observations were recorded regularly on disease incidence of mosaic symptoms in ridge gourd. Disease incidence was calculated on the basis of per cent plant infected. Disease severity was also assessed using 0-4 disease rating scale (Singh et al., 2007). Per cent disease index (PDI) was also calculated. Two year data (2018 and 2019) on PDI were pooled as well as angular transformed and statistically analyzed by off campus CCSHAU, Hisar (Haryana) OPSTAT statistical analysis software in RBD. Per cent disease control was also calculated by following formula:

$$
\begin{aligned}
& \begin{array}{c}
\text { Per cent Disease Control }(\mathrm{PDC})= \\
\begin{array}{c}
\% \text { disease incidence } \\
\text { in control }
\end{array} \\
\frac{\% \text { disease incidence }}{\text { in treatment }} \\
\% \text { disease incidence in control }
\end{array} \text {. } 100
\end{aligned}
$$

\section{Results and Discussion}

Results of pooled data (2018 and 2019) clearly indicated that sprays of all treatments were found effective against mosaic disease than control (Table 1). Mosaic disease in ridge gourd was found with ranging from $15.90-41.51 \%$ disease index (PDI) during 02 years pooled data. Among 11 treatments in their efficacy, imidacloprid (@ 0.05\%) was found the most effective treatment with minimum per cent disease index of $15.90 \%$ and per cent disease reduction (61.69\%) against mosaic disease during rainy season. Next best treatment was neem leaf extract (@ $10 \%$ ) with per cent disease index of $19.34 \%$ and per cent disease reduction $(53.41 \%)$ against this disease which were statistically differ with each other in respect of per cent disease index. After that, tumba fruit extract (@ 10\%) and NSKE (5\%) were also found effective with $21.18 \%$ PDI and $48.97 \%$ (disease reduction) and $23.42 \%$ PDI and per cent disease reduction of $43.57 \%$, respectively which were statistically at par with each other. Although, neem leaf extract (@ 10\%) and tumba fruit extract (@10\%) were also statistically at par with each other in case of PDI. Maximum disease index $(41.51 \%)$ was found in case of control, followed by borex (@ 500 ppm) with per cent disease incidence of $36.89 \%$ which were statistically differ with each other.

Tripathi and Tripathi (1982) found that spraying of leaf extract of neem was most potent in reducing bean common mosaic virus infectivity under filed conditions. Ansari et al., (2007) used botanicals and plant products and found that spraying with neem seed kernel extracts and leaf extract of Thuja and Cupressus proved effective in reducing disease incidence of tomato leaf curl. Venkataravanappa et al., (2011) reported that the field plots sprayed with neem based products was found to be quite effective against yellow vein mosaic disease on okra. Kumar et al., (2015) found most effective botanicals against mosaic disease of elephant foot yam and gave maximum disease reduction of $85.7 \%$. Nagendran et al., (2017) found that application of botanical pesticides 
such as@5\% NSKE or 3\% neem oil was effective against mosaic disease on cucurbits. They also found that spray of neem bio- pesticide (3-5 $\mathrm{ml} / \mathrm{l})$ at 45 DAS was also found effective against yellow vein mosaic disease on okra.

Table.1 Effect of botanicals and inorganic salts against mosaic disease in ridge gourd under filed conditions

\begin{tabular}{|c|c|c|c|c|c|c|}
\hline $\begin{array}{l}\text { S. } \\
\text { No. }\end{array}$ & Treatments & Doses & $\begin{array}{c}\text { Per cent } \\
\text { disease } \\
\text { index (PDI) } \\
\text { of the year } \\
2018\end{array}$ & $\begin{array}{c}\text { Per cent } \\
\text { disease } \\
\text { index of the } \\
\text { year } 2019\end{array}$ & $\begin{array}{c}\text { PDI }(\%) \text { of } \\
\text { pooled } \\
\text { data of } \\
2018 \& \\
2019\end{array}$ & $\begin{array}{l}\text { Per cent } \\
\text { disease } \\
\text { reduction } \\
(\%)\end{array}$ \\
\hline 1. & Neem leaf extract & $5 \%$ & $\begin{array}{c}31.25 \\
*(33.97)\end{array}$ & $\begin{array}{c}26.32 \\
*(30.82)\end{array}$ & $\begin{array}{c}28.78 \\
*(32.39)\end{array}$ & 30.66 \\
\hline 2. & Neem leaf extract & $10 \%$ & $\begin{array}{c}20.42 \\
(26.83)\end{array}$ & $\begin{array}{c}18.27 \\
(25.27)\end{array}$ & $\begin{array}{c}19.34 \\
(26.05)\end{array}$ & 53.41 \\
\hline 3. & NSKE & $5 \%$ & $\begin{array}{c}24.45 \\
(29.57)\end{array}$ & $\begin{array}{c}22.40 \\
(28.21)\end{array}$ & $\begin{array}{c}23.42 \\
(28.89)\end{array}$ & 43.57 \\
\hline 4. & $\begin{array}{l}\text { Tumba fruit } \\
\text { extract }\end{array}$ & $5 \%$ & $\begin{array}{c}33.52 \\
(35.35)\end{array}$ & $\begin{array}{c}29.76 \\
(33.01)\end{array}$ & $\begin{array}{c}31.64 \\
(34.18)\end{array}$ & 23.77 \\
\hline 5. & $\begin{array}{l}\text { Tumba fruit } \\
\text { extract }\end{array}$ & $10 \%$ & $\begin{array}{c}22.36 \\
(28.19)\end{array}$ & $20.0(26.49)$ & $\begin{array}{c}21.18 \\
(27.34)\end{array}$ & 48.97 \\
\hline 6. & Salicylic acid & $500 \mathrm{ppm}$ & $\begin{array}{c}37.14 \\
(37.53)\end{array}$ & $\begin{array}{c}33.58 \\
(35.34)\end{array}$ & $\begin{array}{c}35.36 \\
(36.44)\end{array}$ & 14.82 \\
\hline 7. & Borex & $500 \mathrm{ppm}$ & $\begin{array}{c}38.62 \\
(38.41)\end{array}$ & $\begin{array}{c}35.17 \\
(36.35)\end{array}$ & $\begin{array}{c}36.89 \\
(37.38)\end{array}$ & 11.13 \\
\hline 8. & Aak leaf extract & $5 \%$ & $\begin{array}{c}36.08 \\
(36.89)\end{array}$ & $\begin{array}{c}31.62 \\
(34.19)\end{array}$ & $\begin{array}{c}33.85 \\
(35.54)\end{array}$ & 18.45 \\
\hline 9. & Aak leaf extract & $10 \%$ & $\begin{array}{c}27.83 \\
(31.81)\end{array}$ & $\begin{array}{c}24.56 \\
(29.63)\end{array}$ & $\begin{array}{c}26.19 \\
(30.72)\end{array}$ & 36.91 \\
\hline 10. & Imidacloprid & $0.05 \%$ & $\begin{array}{c}16.67 \\
(24.04)\end{array}$ & $\begin{array}{c}15.13 \\
(22.84)\end{array}$ & $\begin{array}{c}15.90 \\
(23.44)\end{array}$ & 61.69 \\
\hline 11. & Control & - & $\begin{array}{c}43.28 \\
(41.11)\end{array}$ & $\begin{array}{c}39.74 \\
(39.05)\end{array}$ & $\begin{array}{c}41.51 \\
(40.08)\end{array}$ & - \\
\hline & & $\begin{array}{c}\text { SE(m) } \\
\text { CD at } 5 \%\end{array}$ & $\begin{array}{l}1.14 \\
3.37\end{array}$ & $\begin{array}{l}1.33 \\
3.96\end{array}$ & $\begin{array}{l}0.88 \\
2.54\end{array}$ & \\
\hline
\end{tabular}

* Figures in parenthesis are angular transformed values.

\section{References}

Alpa, C M, Kumar, A, Gupta, A and Aggarwal, A. 2010. Fungi toxic effect of biocontrol agent and botanicals on seed mycoflora and seed germination of oilseed crops. Annal of Plant Protection Sciences 18: 434-437.

Ansari, N A, Pathak, Madhavi, Tiwari, H D and Tiwari, J P. (2007). Management to 
tomato leaf curl virus by gymnosperm, neem and insecticides. Annal of Plant Protection Sciences 15: 429-433.

Aykroyd W R. 1963. The nutritive value of Indian foods and the planning of satisfactory diets. ICMR Special Report Series No. 42.

Jain, R. and Agrawal, K. 2011. Bio-efficacy of plant extracts against Pseudomonas syringae pv. syringae causing leaf spot of cluster bean. Annal of Plant Protection Sciences 19: 106-112.

Kumar, P, Shakywar, R C and Khan, M N. 2015. Antiviral activity of botanicals against elephant foot yam infected with mosaic disease. Annal of Plant Protection Sciences 23: 319-322.

More, T A 2010. Arid Horticulture-Making greater strides. Agricultural Spectrum, $\mathrm{I}(\mathrm{X}): 26-29$.

Nagendran, K, Pandey, K K , Rai, A B and Singh, B. (2017). Viruses of Vegetable Crops: Symptomatology, Diagnostics and Management. Technical Bulletin No. 75, ICAR- IIVR, Varanasi, pp. 48.

Pal, D C and Jain, S K. (1998). Tribal Medicine, Naya Prakash, Calcutta, India.

Seshadri, V S. (1986). Cucurbits. Vegetables crops in India. In: T.K. Bose and M.G. Som (Eds.). Naya Prakash, Calcutta, India: 91-164.

Silva, M B, Rosa, M B, Brasileiro, B G, Almeida, V and Silva, C A. 2005. Desenvolvimento de produtos à base de extratos de plantas para o controle de doenças de plantas. In: Venezon, M.,
Paula, J.R. T.J and Pallini, A. (eds). Controle alternativo de pragas e doenças. Viçosa: EPAMIG/CTZM p. 221-246.

Singh, H N, Chauhan, V B and Akram, M. 2007. Screening of pigeonpea germplasm for resistant against sterility mosaic. Annal of Plant Protection Sciences 15: 523-524.

Stangarlin, J R, Kuhn, OJ, Assi, L and Schwan-Estrada K R F. 2011. Control of plant diseases using extracts from medicinal plants and fungi. In: Méndezvilas A. $(e d)$. Science against microbial pathogens: communicating current research and technological advances. Badajoz: Formatex. v. 2, p.1033-1042.

Tripathi, R K R and Tripathi, R N. 1982. Reduction in bean common mosaic virus (BCMV) infectivity vis-à-vis crude leaf extracts of some higher plants. Experimentia 38: 349

Venkataravanappa, V , Krishnareddy, M, Reddy, C N L and Jalali, S. 2011. Management of okra yellow vein mosaic disease through neem products and insecticides. Annal of Plant Protection Sciences 19: 487-488.

Yamaguchi, I. 1996. Pesticides of microbial origin and applications of molecular biology. In: Crop protection agents from nature, natural products and analogues. (Ed. Copping, L. G.), The Royal Society of Chemistry, London, UK, pp. 27-49

\section{How to cite this article:}

Maheshwari, S. K., B. R. Choudhary, P. L. Saroj and Sharma, B. D. 2020. Field Efficacy of Botanicals and Inorganic Salts against Mosaic Disease on Ridge Gourd in Western Rajasthan. Int.J.Curr.Microbiol.App.Sci. 9(07): 1300-1304. doi: https://doi.org/10.20546/ijcmas.2020.907.149 